\title{
EFFECT OF Cysticercus cellulosae FRACTIONS ON THE RESPIRATORY BURST OF PIG NEUTROPHILS
}

\author{
Silvana Marina Piccoli PUGINE(1), Michelle Fernandes de FARIA(1), Antônio Augusto Mendes MAIA(1), Claudia Ribeiro do VALLE(2), Camila BOSCHINI(1),
} Mirele Daiana POLETI(1), Marcia Ramos Monteiro da SILVA(1) \& Mariza Pires DE MELO(1)

\begin{abstract}
SUMMARY
Neutrophils, eosinophils and macrophages are cells that interact with invading parasites and naive hosts have been shown to have anti-parasitic activity. The initial reaction of these leukocytes is the generation of reactive oxygen species (ROS) to play in parasite expulsion. The present work was carried out to study the effect of total extract, scolex and membrane fractions from Cysticercus cellulosae on respiratory burst by pig neutrophils. Hydrogen peroxide $\left(\mathrm{H}_{2} \mathrm{O}_{2}\right)$ production by neutrophils incubated with metacestode fractions from C. cellulosae showed an increase of: 190\% (total extract), 120\% (scolex) and 44\% (membrane). High antioxidant catalatic activity $(33 \%, 28 \%, 28 \%$ by total extract, scolex and membrane, respectively) was observed in neutrophils incubated with metacestode fractions, which could be an attempt at self-protection. Scolex and membrane fractions increased the phagocytic capacity of neutrophils ( $44 \%$ and $28 \%$, respectively). On the other hand, total cysticerci did not alter the phagocytosis, possibly due to modifications in membrane function, caused by high ROS production from neutrophils in the presence of total cysticerci. Total fraction from C. cellulosae is toxic for neutrophils as shown by the decrease in phagocytic capacity, probably caused by high levels of ROS formation. The difference in toxicity of total extract, scolex and membrane fractions on neutrophils can be explained by the presence of an antigenic effect of the vesicular fluid in the total extract of C. cellulosae.
\end{abstract}

KEYWORDS: Leukocyte; Taenia solium; Oxygen; Catalase; Hydrogen peroxide; Superoxide.

\section{INTRODUCTION}

Taeniasis and cysticercosis represent important public health and economic burdens for many underdeveloped countries. The infection process has produced an intimate contact between the parasites and activated components of their host's immune system. Neutrophils, eosinophils and macrophages are cells to interact with invading parasites and naive hosts have been shown to have antiparasitic activity ${ }^{10,21}$. The initial reaction of these cells is the generation of reactive oxygen species (ROS) to play a part in the expulsion of intestinal parasites ${ }^{9}$. An increase of ROS by these cells has been correlated with respiratory burst and involves a sudden stimulus-induced increase in non-mitochondrial oxidative metabolism ${ }^{18}$.

The respiratory burst in leukocytes is characterized by activation of a NADPH-dependent membrane-associated oxidase that produces superoxide anion $\left(\mathrm{O}_{2}{ }^{-}\right)$from $\mathrm{O}_{2}$. The $\mathrm{O}_{2}{ }^{-}$may be subsequently converted into hydrogen peroxide $\left(\mathrm{H}_{2} \mathrm{O}_{2}\right)$, the hydroxyl radical, singlet oxygen and oxidized halogens. These cells are partly protected from the toxicity of ROS generated intracellularly by activities of antioxidant enzymes: superoxide dismutase (SOD); glutathione peroxidase (GSH-Px); glutathione reductase (GSH-Rd) and catalase (CAT) ${ }^{6}$.
Cysticercosis is an infection caused by Taenia solium metacestode (cysticerci) and is a very important medical and veterinary problem, since establishment of the larva is possible in any of the body's tissues ${ }^{12}$. Cysticercus cellulosae antigen has been demonstrating particular importance in studies to detect host immune response. The cysticercosis caused by $T$. solium induces several immunomodulatory effects ${ }^{14,22}$, including the inhibition of classical and alternative pathways of complement activation in humans ${ }^{11}$. However, the effect of $C$. cellulosae on neutrophil function has not been determined. The present work was carried out to study the effect of total extract, scolex and membrane fractions from $C$. cellulosae on the respiratory burst of pig neutrophils. This model is important to clarify the effect of $C$. cellulosae on the mechanism of respiratory burst activity of neutrophils. The following parameters were examined: i) production of $\mathrm{H}_{2} \mathrm{O}_{2}$; ii) phagocytosis capacity; and iii) activities of antioxidant enzymes (SOD, GSH-Px and CAT).

\section{MATERIAL AND METHODS}

All chemical reagents and enzymes were of analytical grade and obtained from Sigma Chemical Company (St. Louis, MO, USA). 


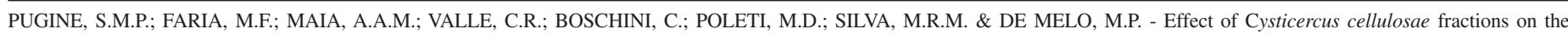
respiratory burst of pig neutrophils. Rev. Inst. Med. trop. S. Paulo, 47(2):91-94, 2005.

T. solium metacestodes were obtained by dissection of muscles from naturally infected pigs. The cysts were washed six times in saline $(0.9 \% \mathrm{NaCl}, \mathrm{w} / \mathrm{v})$ and stored at $-80{ }^{\circ} \mathrm{C}$. Total extract obtained from frozen worms were thawed and homogenized in saline 1:10 (w/v), using glass homogenizers cooled in ice. The supernatant was removed, sonicated (20 khz) during 30 seconds for four cycles in an Eppendorf tube held in ice and centrifuged at $15,000 \times \mathrm{g}$ for $30 \mathrm{~min}$ at $4{ }^{\circ} \mathrm{C}$. Phenylmethylsulfonyl fluoride (PMSF, $0.4 \mathrm{mM}$ final concentration) was added to the resultant solution for inhibition of the activity of proteases and stored in aliquots at $-20{ }^{\circ} \mathrm{C}$. Scolex and membrane fractions were obtained from cysticerci after being thawed and the fractions dissected. The preparation of the scolex and membrane fractions followed the same procedure used for total extract.

Neutrophils were obtained from the blood of male pigs. The blood was collected by venipuncture into EDTA containing tubes. Neutrophils were separated using Percoll gradients (density $1.08 \mathrm{~g} / \mathrm{mL}$ ) and red blood cells were removed by hypotonic shock, before resuspension in phosphate-buffered saline (10 mM phosphate buffer, $\mathrm{pH} 7.4,136 \mathrm{mM}$ $\mathrm{NaCl}, 2.7 \mathrm{mM} \mathrm{KCl}$; PBS). The number of viable cells was determined by exclusion of Trypan solution $(1 \%)$ and counted in a Neubauer chamber under an optical microscope.

Phagocytosis was determined by counting the cells that had engulfed three or more particles of opsonized zymosan in a Neubauer chamber. Zymosan (35 mg in $100 \mathrm{~mL}$ PBS) was boiled for $30 \mathrm{~min}$ and washed twice with PBS before use. Subsequently, the zymosan particles were resuspended $(14 \mathrm{mg} / \mathrm{mL}$ in PBS). For opsonization, $0.5 \mathrm{~mL}$ zymosan particles were mixed with $0.5 \mathrm{~mL}$ pig serum and incubated for $30 \mathrm{~min}$ at $37{ }^{\circ} \mathrm{C}$. The opsonized zymosan particles were washed and resuspended at $1 \mathrm{mg} / \mathrm{mL}$ in PBS. Neutrophils were incubated (2.0 x $10^{6}$ cell $/ \mathrm{mL}$ ) at $37{ }^{\circ} \mathrm{C}$ for $30 \mathrm{~min}$ in $1 \mathrm{~mL} \mathrm{PBS}$ with $2 \%(\mathrm{w} / \mathrm{v})$ defatted bovine serum albumin in the presence of glucose $(5 \mathrm{mM})$ containing opsonized zymosan. Placing the flasks on ice for $10 \mathrm{~min}$ stopped the phagocytosis. Phorbol 12-myristate 13-acetate (PMA; $100 \mathrm{ng}$ ) was used for cell stimulation.

Hydrogen peroxide production was measured using the phenol red method $^{16}$, which is based on horseradish peroxidase(HRP)-dependent conversion of phenol red by $\mathrm{H}_{2} \mathrm{O}_{2}$ into a colored compound. Briefly, the cells were incubated in the presence of glucose $(5 \mathrm{mM})$ and a solution of phenol red and HRP at $37^{\circ} \mathrm{C}$ for $45 \mathrm{~min}$. After this period, the reaction was stopped with $10 \mu \mathrm{L}$ of $1 \mathrm{M} \mathrm{NaOH}$, and the amount of the product formed was spectrophotometrically evaluated at $620 \mathrm{~nm}$. Phorbol 12-myristate 13-acetate (PMA; $100 \mathrm{ng}$ ) was used for cell stimulation.

The extraction medium for the measurements of SOD, CAT and GSH-Px activities consisted of $0.1 \mathrm{mM}$ sodium phosphate buffer at $\mathrm{pH}$ 7.5. The enzyme activity was determined during three minutes and was expressed in $\mu \mathrm{mol}$ per $\mathrm{mg}$ of protein. Catalatic activity was measured following $\mathrm{H}_{2} \mathrm{O}_{2}$ reduction at $240 \mathrm{~nm}^{2}$. Superoxide dismutase activity was determined by its inhibitory effect on the rate of superoxide-dependent reduction of nitroblue tetrazolium (NBT) by xanthine-xanthine oxidase at $560 \mathrm{~nm}^{1}$. The activity of glutathione peroxidase was determined by measuring the rate of NADPH oxidation at $340 \mathrm{~nm}$ with the concurrent reduction of oxidized glutathione.
The protein content of cell preparations was measured by the method of BRADFORD ${ }^{3}$, using bovine serum albumin (BSA) as standard. Data are expressed as mean \pm standard deviation (SD). Statistical analysis was by ANOVA and Tukey's test with significance level set at $\mathrm{p}<0.05$.

\section{RESULTS AND DISCUSSION}

Dose-response curve of $\mathrm{H}_{2} \mathrm{O}_{2}$ production to total extract from $C$. cellulosae was performed (Fig. 1). The cells were incubated in the presence of this extract at the following concentrations: $0.07,0.13$, $0.21,0.40,0.52$ and $0.57 \mathrm{mg}$ of protein $/ \mathrm{mL}$. Total extract promoted an increase of $\mathrm{H}_{2} \mathrm{O}_{2}$ production, when compared with control conditions, by $100 \%$ and $170 \%$ at 0.07 and $0.13 \mathrm{mg}$ of protein, respectively. Therefore, concentrations over $0.13 \mathrm{mg}$ of protein cause the maximum effect of total extract, and $0.57 \mathrm{mg}$ of protein was chosen for the remaining measurements. Table 1 presents $\mathrm{H}_{2} \mathrm{O}_{2}$ production by nonstimulated and PMA-stimulated neutrophils incubated in the presence of total extract, scolex and membrane fractions. These results showed a significant increase in the production of $\mathrm{H}_{2} \mathrm{O}_{2}$ by 1.9, 1.2 and 0.44 fold, respectively, when compared to control (absence of cysticerci). A similar effect was found in PMA-stimulated neutrophils by total, scolex and membrane fractions: 2.6, 2.4 and 2.5 times, respectively, for comparison with PMA-control conditions. But, $\mathrm{H}_{2} \mathrm{O}_{2}$ production by neutrophils in presence of PMA did not show a significant alteration among the fraction exposures. These treatments did not induce cell death, as determined by exclusion of Trypan blue solution (data not shown).

The effect of total extract, scolex and membrane fractions from $C$. cellulosae on phagocytic capacity by nonstimulated or PMA-stimulated neutrophils was showed in Table 1 . The scolex and membrane fractions raised the phagocytic capacity for nonstimulated neutrophils (44\% and $28 \%$, respectively) compared to control conditions. However, the total

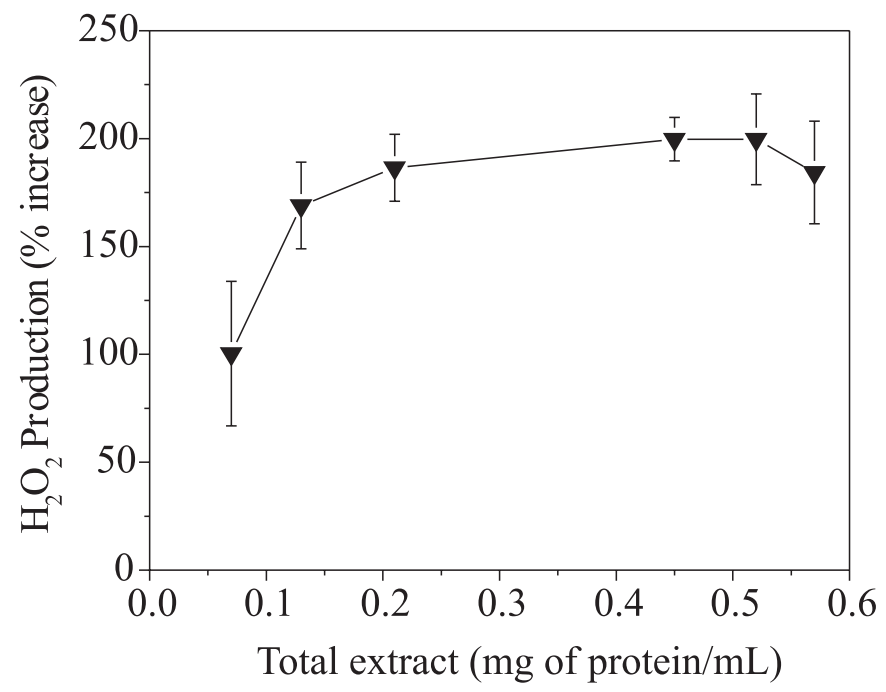

Fig. 1- Dose-response curve of $\mathrm{H}_{2} \mathrm{O}_{2}$ production by pig's neutrophils and total extract concentration from $C$. cellulosae. The values are expressed in percentage of inhibition against control condition (absence of fraction) and presented as mean \pm SD (Standard Deviation) of six measurements from three experiments. 


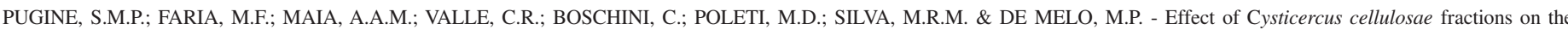
respiratory burst of pig neutrophils. Rev. Inst. Med. trop. S. Paulo, 47(2):91-94, 2005.

extract did not alter the phagocytic capacity in nonstimulated neutrophils. The phagocytic capacity in presence of PMA increased by $46 \%, 45 \%$ and $46 \%$ by neutrophil incubated with total extract, scolex or membrane fraction respectively, compared to control-PMA. On the other hand, another significant effect was observed in phagocytic capacity between the metacestode fraction exposures. Under these conditions they were nontoxic to neutrophils, as shown by Trypan blue exclusion (data not shown).

An activity of CAT, SOD and GSH-Px on neutrophils was determined after one hour incubation in the presence and absence of total extract, scolex and membrane from C. cellulosae (Table 2). Catalatic activity on neutrophils showed an increase of $33 \%, 28 \%$ and $28 \%$ by presence of total extract, scolex and membrane fractions, respectively. These results show that all stimuli seem to significantly affect the activity of CAT under these conditions. The activity of SOD and GSH-Px was determined and the cysticerci fractions did not alter the activity of these enzymes. The production of $\mathrm{H}_{2} \mathrm{O}_{2}$ by neutrophils incubated with metacestode fractions from $C$. cellulosae increased. Concomitantly with the increase in $\mathrm{H}_{2} \mathrm{O}_{2}$ production, catalatic activity was elevated in neutrophils incubated with the fractions of metacestodes, which could be an attempt at self-protection. Consequently, the high ROS production by neutrophils in the presence of total cysticerci extract may be responsible for the modifications in membrane function, which could in turn lead to a decrease in phagocytic capacity.
Evidence has been accumulating that increased reactive oxygen species production by neutrophils may be related to parasite expulsion ${ }^{20}$. Expulsion of Nipposstrongylus brasiliensis by mice was inhibited by administration of the antioxidant ${ }^{19}$. NIWA \& MIYAZATO ${ }^{13}$ demonstrated that production of reactive oxygen species by mouse intestinal eosinophils in response to Hymenolepis nana larvae and showed higher activation of NADPH-oxidase in eosinophils from challenged mice. Inhibition of NADPH-oxidase in vivo interfered in the removal of Haemonchus contortus larva from the intestine?

Previous studies have shown that extracts of excretory/secretory products from several helminthes present enzymatic and non-enzymatic antioxidant properties ${ }^{8,15}$. Catalase is absent or present at only low activity in many parasites ${ }^{7}$. However, superoxide dismutase is secreted by various parasites ${ }^{4,17}$, suggesting an interaction with superoxide anion encountered in the parasite's environment. Taenia solium has a $\mathrm{Cu} / \mathrm{Zn}$ superoxide dismutase type of enzyme ${ }^{5}$. In our studies, antioxidant enzyme activities were measured directly in different fractions from C. cellulosae (Table 2). All fractions of $C$. cellulosae did not present CAT and GSH-Px activities. However, SOD activity was found in total extract and membrane fractions and this enzyme activity in the membrane fraction is $45 \%$ higher than the activity found in total extract. These results suggest that superoxide dismutase from cysticerci fractions may be involved in attenuating the peroxide production by neutrophils in the presence of membrane extract.

Table 1

Percentage increase in $\mathrm{H}_{2} \mathrm{O}_{2}$ production and phagocytosis capacity in nonstimulated and phorbol 12-myristate 13-acetate (PMA)-stimulated neutrophils incubated in absence and presence of total extract-F1, scolex-F2 and membrane-F3 fraction from C. cellulosae

\begin{tabular}{lcccc}
\hline & PMA & F1 & F2 & F3 \\
\hline $\mathbf{H}_{2} \mathbf{O}_{2}$ production & - & $189.7 \pm 25.1^{*}$ & $120.6 \pm 8.6^{*}$ & $44.0 \pm 7.2^{*}$ \\
Phagocytosis & + & $260.2 \pm 20.0^{\#}$ & $240.0 \pm 19.0^{\#}$ & $250.0 \pm 25.0^{\#}$ \\
& - & $11.0 \pm 0.2$ & $44.0 \pm 0.4^{*}$ & $28.1 \pm 0.2^{*}$ \\
& + & $46.0 \pm 0.4^{\#}$ & $45.1 \pm 0.4^{\#}$ & $46.5 \pm 0.4^{\#}$ \\
\hline
\end{tabular}

The values are presented as mean \pm SD (Standard Deviation) of six measurements from three experiments. *(p $<0.05)$ compared with the control nonstimulated neutrophils and ${ }^{\#}(\mathrm{p}<0.05)$ compared with control PMA-stimulated neutrophils.

Table 2

Activities ( $\mu \mathrm{mol}$ per mg of protein) of superoxide dismutase-SOD, catalase-CAT and glutathione peroxidase-GSH-Px determined in neutrophils incubated during one hour in the absence and presence of total extract-F1, scolex-F2 and membrane-F3 fractions from C. cellulosae and measured in these different fractions from C. cellulosae

\begin{tabular}{lccc}
\hline & SOD & CAT & GSH-Px \\
\hline Fractions & $23.600 \pm 0.005$ & - & - \\
F1 & - & - & - \\
F2 & $42.900 \pm 0.004^{\#}$ & - & $0.276 \pm 0.003$ \\
F3 & $4.90 \pm 0.05$ & $0.210 \pm 0.007$ & $0.272 \pm 0.003$ \\
Neutrophils & $4.80 \pm 0.04$ & $0.280 \pm 0.016^{*}$ & $0.275 \pm 0.002$ \\
Control & $5.00 \pm 0.05$ & $0.270 \pm 0.005^{*}$ & $0.270 \pm 0.004$ \\
Presence of F1 & $4.8 \pm 0.04$ & $0.270 \pm 0.006^{*}$ & \\
Presence of F2 & Presence of F3 & & \\
\hline
\end{tabular}

The values are presented as mean \pm SD (Standard Deviation) of six determinations from three experiments.* $(\mathrm{p}<0.05)$ compared with the control (absence of fractions) and ${ }^{\#}(\mathrm{p}<0.05)$ compared with F1 (total extract). 


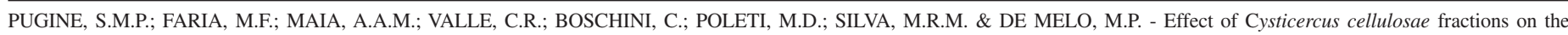
respiratory burst of pig neutrophils. Rev. Inst. Med. trop. S. Paulo, 47(2):91-94, 2005.

The results presented here, led us to conclude that total fraction from $C$. cellulosae is toxic for neutrophils as shown by the decrease in phagocytic capacity, probably caused by high levels of ROS formation. The difference in the toxicity of total extract, scolex and membrane fractions on neutrophils can be explained by the presence of an antigenic effect of the vesicular fluid in the total extract of C. cellulosae.

\section{RESUMO}

\section{Efeito de frações de Cysticercus cellulosae sobre a explosão respiratória de neutrófilos de suínos}

Neutrófilos, eosinófilos e macrófagos são células que interagem com os parasitas no corpo do hospedeiro desenvolvendo atividade antiparasitária. A reação inicial destes leucócitos é a geração de espécies reativas de oxigênio (ERO) a fim de expulsar os parasitas. No presente trabalho estudou-se o efeito da fração total, de escolex e de membrana de Cysticercus cellulosae sobre a explosão respiratória de neutrófilos de suínos. A produção de peróxido de hidrogênio $\left(\mathrm{H}_{2} \mathrm{O}_{2}\right)$ pelos neutrófilos incubados com as frações de C. cellulosae apresentou acréscimo de $190 \%$ (extrato total), 120\% (escolex) e $44 \%$ (membrana). Alta atividade de catalase $(33 \%, 28 \%$ e $28 \%$ para extrato total, escolex e membrana respectivamente) foi observada nos neutrófilos incubados com as frações de metacestodeo, podendo representar a própria proteção celular do neutrófilo. Frações de escolex e de membrana aumentaram a capacidade fagocitária dos neutrófilos ( $44 \%$ e $28 \%$, respectivamente). Por outro lado, a fração total do cisticerco não alterou a capacidade fagocitária dos neutrófilos, o que pode estar relacionada com modificações na função da membrana celular causadas pela alta produção de ERO na presença da fração total. O extrato total de $C$. cellulosae é tóxico para os neutrófilos, indicada pela diminuição da capacidade fagocitária, provavelmente pela indução de alto nível de ERO. A diferença de toxicidade do extrato total, de escolex e de membrana para os neutrófilos pode ocorrer pelo efeito antigênico presente no fluido vesicular no extrato total de $C$. cellulosae.

\section{ACKNOWLEDGMENTS}

Thanks are due to Prof. Dr. Marcus Antonio Zanetti from PCAPS/ USP/Pirassununga for the generous donation and maintenance of the animals during the experiments. This research received financial support from FAPESP and CNPq.

\section{REFERENCES}

1. BEAUCHAMP, C. \& FRIDOVICH, I. - Superoxid dismutase: improved assays and an assay applicable to acrylamide gels. Analyt. Biochem., 44: 276-287, 1971.

2. BEERS Jr., R.F. \& SIZER, I.W. - A spectrophotometric method of measuring the breakdown of hydrogen peroxide by catalase. J. biol. Chem., 195: 133-140, 1952.

3. BRADFORD, M.M. - A rapid and sensitive method for the quantitation of microgram quantities of protein utilizing the principle of protein-dye binding. Analyt. Biochem., 72: 248-254, 1976.

4. CALLAHAN, H.L.; CROUCH, R.K. \& JAMES, E.R. - Dirofilaria immitis superoxide dismutase: purification and characterization. Molec. Biochem. Parasit., 49: 245$251,1991$.
5. CASTELLANOS-GONZÁLES, A.; JIMÉNEZ, L. \& LANDA, A. - Cloning, production and characterization of a recombinant $\mathrm{Cu} / \mathrm{Zn}$ superoxide dismutase from Taenia solium. Int. J. Parasit., 32: 1175-1182, 2002.

6. HALLIWELL, B. \& GUTTERIDGE, J.M.C. - Oxygen free radicals and iron in relation to biology and medicine: some problems and concepts. Arch. Biochem. Biophys., 246: 501-514, 1986.

7. HENKLE-DUHRSEN, K. \& KAMPKOTTER, A. - Antioxidant enzyme families in parasitic nematodes. Molec. Biochem. Parasit., 114: 129-142, 2001.

8. JEFFERIES, J.R.; TURNER, R.J. \& BARRETT, J. - Effect of Fasciola hepatica excretorysecretory products on the metabolic burst of sheep and human neutrophils. Int. J. Parasit., 27: 1025-1029, 1997.

9. KOTZE, A.C. \& McCLURE, S.J. - Haemonchus contortus utilises catalase in defence against exogenous hydrogen peroxide in vitro. Int. J. Parasit., 31: 1563-1571, 2001.

10. KUMARATILAKE, L.M.; FERRANTE, A.; ROBINSON, B.S.; JAEGER, T. \& POULOS, A. - Enhancement of neutrophil-mediated killing of Plasmodium falciparum asexual blood forms by fatty acids: importance of fatty acid structure. Infect. Immun., 65: 4152-4157, 1997.

11. MEZA-LUCAS, A.; CARMONA-MIRANDA, L.; GARCIA-JERONIMO, R.C. et al. Limited and short-lasting humoral response in Taenia solium: seropositive households compared with patients with neurocysticercosis. Amer. J. trop. Med. Hyg., 69: 223 $227,2003$.

12. MONROY-OSTRIA, A.; MONROY-OSTRIA, T.J.; GOMEZ, G.J. \& HERNANDEZ, M.O. - Some studies on the experimental infection of golden hamsters with Taenia solium. Rev. lat.-amer. Microbiol., 35: 91-98, 1993.

13. NIWA, A. \& MIYAZATO, T. - Reactive oxygen intermediates from eosinophils in mice infected with Hymenolepis nana. Paras. Immunol., 18: 285-295, 1996.

14. PÉREZ-TORRES, A.; USTARROZ, M.; CONSTANTINO, F. \& VILLALOBOS, N. de A.A. - Taenia solium cysticercosis: lymphocytes in the inflammatory reaction in naturally infected pigs. Parasit. Res., 88: 150-152, 2002.

15. PIACENZA, L.; RADI, R.; GONI, F. \& CARMONA, C. - CuZn superoxide dismutase activities from Fasciola hepatica. Parasitology, 117: 555-562, 1998.

16. PICK, E. \& MIZEL, D. - Rapid microassays for measurement of superoxide and hydrogen-peroxide production by macrophages in culture using an automatic enzyme-immunoassay reader. J. immunol. Meth., 46: 211-226, 1981.

17. RHOADS, M.L. - Trichinella spiralis: identification and purification of superoxidedismutase. Exp. Parasit., 56: 41-54, 1983.

18. ROSEN, G.M.; POU, S.; RAMOS, C.L.; COHEN, M.S. \& BRITIGAN, B.E. - Free radicals and phagocytic cells. FASEB J., 9: 200-209, 1995.

19. SMITH, N.C. \& BRYANT, C. - Free-radical generation during primary infections with Nippostrongylus brasiliensis. Paras. Immunol., 11: 147-160, 1989.

20. SMITH, N.C.; OVINGTON, K.S. \& BORAY, J.C. - Fasciola hepatica: free-radical generation by peritoneal leukocytes in challenged rodents. Int. J. Parasit., 22: 281286, 1992.

21. STEWART, G.L.; SHUPE, K.; KIM, I. et al. - Antibody-dependent neutrophil-mediated killing of Achantamoeba castellanii. Int. J. Parasit., 24: 739-742, 1994.

22. TATO, P.; WHITE Jr., A.C.; WILLMS, K. et al. - Immunosuppression and inhibition of inflammation in mice induced by a small Taenia solium RNA-peptide to implanted Taenia solium metacestodes. Parasit. Res., 82: 590-597, 1996.

Received: 17 May 2004

Accepted: 1 December 2004 